\title{
Managing an Environmental-Friendly Coal Mining Wastewater Processing
}

\author{
Muhammad Naswir ${ }^{1, *}$, Ria Purnama Sari ${ }^{1}$, Rosyani $^{1}$ \\ ${ }^{1}$ Master Program of Environmental Engineering, Universitas Jambi. Street: Arif Rahman Hakim, Telanai Pura, \\ Jambi City 36361 \\ *Corresponding Author: m.naswir@yahoo.com
}

\section{Article history}

Received: 10-03-2020

Revised: 04-04-2020

Accepted: 18-04-2020
DOI: $10.31629 /$ jit.v1i1.2136

\begin{abstract}
Jambi is one of the provinces in Indonesia that has an abundance coal potential. One of the companies that holds the Mining-Business License (IUP) for Coal mining production and operations is PT. XYZ, which is chosen to be the source of samples for this research. One of the negative impacts caused by coal mining activities is the wastewater emerge from both mining and stockpile activities. Unprocessed wastewater can pollute the environment, particularly the surface water and ground water around the mining site. Materials utilized in managing coal mine wastewater in this research are bentonite (natural and activated) and limestone from clamshells. Bentonite is expected to be able to absorb TSS, Fe, Mn and $\mathrm{Hg}$ values, while clamshells to increase the $\mathrm{pH}$ value in coal mine wastewater. This research aims to determine the ability of clamshell bentonite and limestone in processing coal mine wastewater. The samples in this research are amounted to 19 consisting of 1 control sample and 18 treatment samples. The treatments are made in 6 mass variations and 3 variations of contact time. A combination of 1 gram of material is contacted with $250 \mathrm{ml}$ of coal mine wastewater. The characteristics of coal mine wastewater from PT. XYZ based on the samples taken are as follows: pH 4,40, TSS $66 \mathrm{mg} / \mathrm{l}, \mathrm{Fe} 0,998$ $\mathrm{mg} / \mathrm{l}, \mathrm{Mn} 7,340 \mathrm{mg} / \mathrm{l}$, dan $\mathrm{Hg}$ 0,00076 mg/l. The results of this research show that the compilation of bentonite and limestone from clamshells is able to reduce the parameters of coal mine wastewater. The absorption efficiency of the compilation of bentonite and limestone in decreasing the parameters of coal mine wastewater has varied values with the average of: $\mathrm{pH} 68,62 \%$, TSS 90,91\%, $\mathrm{Fe} 97,60 \%$, Mn 26,71\%, and $\mathrm{Hg} 96,05 \%$. Mass variations and contact time influence the decrease in coal mine wastewater parameters. The treatment on variations of 0.75 grams of activated clamshell bentonite and 0.25 grams of clamshell limestone with 30 minutes contact time is the treatment that produces wastewater that meets the environmental quality standards, which are $\mathrm{pH} 7,16$ from $6-9$ of environmental quality standards value, TSS $6 \mathrm{mg} / \mathrm{l}$ from $400 \mathrm{mg} / \mathrm{l}$ of environmental quality standards value, $\mathrm{Fe}<0,02 \mathrm{mg} / \mathrm{l}$ from $7 \mathrm{mg} / \mathrm{l}$ of environmental quality standards value, and $\mathrm{Hg}$ $<0,00003 \mathrm{mg} / \mathrm{l}$ from $0,002 \mathrm{mg} / \mathrm{l}$ of environmental quality standards value. With good management, it is expected that the impacts caused by waste water from coal mining can be minimized in order to achieve environmentally friendly mining activities
\end{abstract}

Keywords: coal mining, wastewater, treatment, and environmental quality 


\section{Introduction}

Mining is one of great potential industries in Indonesia. A great number of industries operating throughout the islands of Indonesia indicate its abundance of natural resources. However, these mining activities are like a two-sided coin. Though it is the very fact that the existence of mining industries has played a major importance in increasing the national economic performance, on the other side, mining activities have also made us pay more attention and concern as they have caused in such tremendous negative impacts on environment. One of those potential commodities in Indonesia is coal mining industry.

Jambi is one of provinces that has an abundance of coal resource. In 2017, it reached 2.115,70 million of tons, noted for its production for 3.065.114 tons up to the second three-month term and managed by 112 operating coal mining companies [1]. One of the companies that holds (IUP) Mining-Business Licenses for Coal Production and Operation in the Province of Jambi is PT. XYZ. The coal mining activities are expected to become one of the solutions in fulfilling the needs of energy sources. The problem is that the typical coal mining activities are operated in open mining areas, which in turn, impact on environment. The continual activities of this open mining method, of exploiting or coal mining is one of potential activities to produce wastewater. Unprocessed wastewater can pollute the surface water and ground water around the mining site.

From the above, it is urgent that the company find proper solution in handling polluted water caused by wastewater processing resulted from coal mining activities. The alternative coal mining wastewater processing proposed is by utilizing bentonite that is quite accessible in the Province of Jambi. Bentonite is expected to be able to adsorb the pollutant contents in the wastewater caused by coal mining activities, such as, suspended residues (TSS), Total Iron (Fe), Total Mangan (Mn), and Mercury $(\mathrm{Hg})$. Bentonite has the property of dominant adsorbents due to its very small colloidsize particles and high ionic surface capacity [2].

Bentonite is considered as a clay mineral that has property of swelling, exchangeable cations, and wide surface. These properties make it suitable for the use of adsorbent. To increase the capacity of its adsorbent and ionic removal force, bentonite is to be activated beforehand by heating and modification of acid to increase its porosity, surface and acidity.

Coal mining activities resulting in wastewater have property of acid which has $\mathrm{pH}$ less than 6 , then bentonite is to be compiled with limestone. Limestone used in this research derives from clamshells. Clamshells contain with $\mathrm{CaCO} 3$, and can be reduced by the process of heating to be $\mathrm{CaO}$ [3]. These compounds have property of bases and are able to reduce the acidity rate $(\mathrm{pH})$ of wastewater from coal mining activities.

This research is to find out the force of bentonite adsorption compiled with limestone of clamshells on the value of $\mathrm{pH}$, Suspended Residue (TSS), Total Iron ( $\mathrm{Fe}$ ) Total, Total Mangan (Mn), and Mercury $(\mathrm{Hg})$ containing in wastewater from coal mining activities. By utilizing bentonite and clamshells as the wastewater processing materials of coal mining activities, it is expected that environmentally-friendly coal mining activities can be achieved

\section{Research Methodology}

\subsection{Sampling}

Method used in collecting samples is purposive sampling technique, in which the samples are chosen and collected by the researcher him or herself. The samples used in this research are wastewater taken from coal mining activities in IPAL (settling pond) of the mining company. Sampling technique is in compliance with SNI 6989.59:2008 on Method of Wastewater Sampling.

\subsection{Procedure}

The sample of wastewater of coal mining activities taken from inlet IPAL (the first settling pond) was analyzed in the lab to find out its value of pH, Suspended Residue (TSS), Total Iron (Fe), Total Mangan (Mn), and Mercury ( $\mathrm{Hg}$ ) containing in the wastewater. The result of analysis was to compare the quality of wastewater to be contacted with bentonite and limestone.

\subsection{Preparation}

The amount of bentonite applied was 200 grams. It was then cleaned by using aquades, dried by heating in the oven at $105 \mathrm{C}$ for 3 hours to remove its water content. The dry bentonite was grounded well, filtered with 100 meshes. The filtered bentonite was taken and kept in desiccator before the next process was continued. 
50 grams bentonite of 100 meshes was put into Erlenmeyer containing with $200 \mathrm{~mL} \mathrm{HCl} \mathrm{1,0} \mathrm{M.}$ Next, it was stirred for 1 hour with the speed of 200 rpm. This process was purposed to enlarge the porosity of bentonite surface. Then, it was filtered and cleaned by using aquades. Its residues were heated at $200 \mathrm{C}$ for 1 hour. After being dry, it was grounded well and filtered with 120 meshes, kept in desiccators. Finally, activated bentonite was formed.

Clamshells processing started with the cleaning of clamshells from any disturbing dirt by using water or aquades. Then, they were dried and burnt. Clamshells burning process used furnace at $600 \mathrm{C}$ for 5 hours. The burnt clamshells were then cooled down and smoothed into powder.

\subsection{Treatment}

7 samples of wastewater, each volume of $250 \mathrm{ml}$, of coal mining from PT. XYZ were prepared. Sample 1 was wastewater of pure coal mining (without adding bentonite and limestone of clamshells) which was then to be analyzed in the Laboratory of Regional Environmental Office of the Province of Jambi to find out the properties of wastewater of coal mining from PT. XYZ in compliance with the environmental quality standard and serve as the control or rate of samples to be contacted with bentonite and limestone of clamshells. Sample 2 to 7 would each be contacted with bentonite and limestone of clamshells with the combined weight of 1 gram to be treated as follows:

1. Sample 2 was combined $75 \%$ of natural bentonite and $25 \%$ of limestone of clamshells

2. Sample 3 was combined $50 \%$ of natural bentonite and $50 \%$ of limestone of clamshells

3. Sample 4 was combined $25 \%$ of natural bentonite and $75 \%$ of limestone of clamshells

4. Sample 5 was combined $75 \%$ of activated bentonite and $25 \%$ of limestone of clamshells

5. Sample 6 was combined $50 \%$ of activated bentonite and $50 \%$ of limestone of clamshells

6. Sample 7 was combined $25 \%$ of activated bentonite and $75 \%$ of limestone of clamshells.

Afterwards, each sample (sample 2 to 7) was stirred with variants of contacting time for 30,60 , and 90 minutes with stirring speed of $200 \mathrm{rpm}$. Next, it was distilled using filter paper to separate its filtrates and residues. The filtrates gained were then analyzed to find out its value of $\mathrm{pH}$, Suspended
Residue (TSS), Total Iron (Fe), Total Mangan (Mn), and Mercury (Hg).

\subsection{Measuring Parameter}

Measuring $\mathrm{pH}$ uses $\mathrm{pH}$ meter which has been calibrated with buffer solution at $\mathrm{pH} 4$ and 7 . Suspended Residue (TSS) Testing applied gravimetric method. Heavy metals containing in the filtrates of wastewater samples from coal mining activities were treated and analyzed by using SSA method (Atomic Absorption Spectrophotometer).

\subsection{Data Analysis}

In the light of purpose and hypotheses of the research, data collected from the result of laboratory analysis was then analyzed further:

1. To compare in compliance with the environmental quality standard so as to figure out the properties of wastewater of coal mining.

2. To compare the result of wastewater sample laboratory analysis of the coal mining between the sample which was treated and not treated to find out its capacity to compiled bentonite with limestone of clamshells in reducing the parameter of wastewater of coal mining.

3. To calculate the result of wastewater sample laboratory analysis of the coal mining before and after being treated to figure out the adsorption efficiency of compiled bentonite with limestone in reducing the parameter of wastewater of coal mining.

4. To interpret the result of wastewater sample laboratory analysis of the coal mining in the form of graphic to find out the effect of mass and contacting time on the compiled bentonite with limestone in reducing the parameter of wastewater of coal mining

\section{Result and Discussion}

Collecting the samples of wastewater of coal mining activities in this research was from the first pond (which is the settling pond of wastewater from coal mining sites and stockpile) at the settling pond of PT. XYZ. The result of wastewater analysis of coal mining (natural) can be seen in Table 1. 
M Naswir et al., Journal of Innovation and Technology, April 2020, Vol. 1 No. 1. DOI: 10.31629/jit.v1i1.2136

Table 1. Properties of AAT

\begin{tabular}{c|c|c|c|c}
\hline No. & Parameter Analysis & Unit & $\begin{array}{c}\text { Result of } \\
\text { Testing }\end{array}$ & $\begin{array}{c}\text { Quality } \\
\text { Standard }\end{array}$ \\
\hline 1. & $\mathrm{pH}$ & - & $\mathbf{4 , 4 0}$ & $6,0-9,0$ \\
\hline 2. & TSS & $\mathrm{mg} / \mathrm{l}$ & 66 & 400 \\
\hline 3. & Total Iron $(\mathrm{Fe})$ & $\mathrm{mg} / \mathrm{l}$ & 0,998 & 7 \\
\hline 4. & Total Mangan $(\mathrm{Mn})$ & $\mathrm{mg} / \mathrm{l}$ & $\mathbf{7 , 3 4 0}$ & 4 \\
\hline
\end{tabular}

Based on the above data, the properties of wastewater of coal mining in PT. XYZ in compliance with the standard of environmental quality can be detected that its quality of wastewater is not safe yet to be dumped into the body of water. The reasons are that some parameter exceeds the value of environmental quality standard, in which it has $\mathrm{pH}$ at the value of 4,4 from the standard ones at $6-9$ and $\mathrm{Mn}$ at the value of 7,34 from the standard one at 4 .

The visual condition of wastewater of coal mining of PT. XYZ in the settling pond appears transparent/not muddy but looks golden and without odors. The compiled bentonite with limestone of clamshells in reducing the wastewater parameter of coal mining samples was contacted with various bentonite and limestone of clamshells. It was prepared and analyzed in the Laboratory of Regional Environmental Office of the Province of Jambi. The Result of analysis can be seen in Table 2 as follows:

Table 2. Analysis of AAT Before and After Treatment

\begin{tabular}{|c|c|c|c|c|c|c|}
\hline \multirow{2}{*}{ No. } & \multirow{2}{*}{ Description } & \multicolumn{5}{|c|}{ Parameter } \\
\hline & & pH & TSS & $\mathbf{F e}$ & Mn & Hg \\
\hline 1. & Untreated & 4,40 & 66 & 0,998 & 7,340 & $\begin{array}{c}0,0007 \\
6\end{array}$ \\
\hline 2. & $\begin{array}{l}75 \% \text { BAL : } 25 \% \\
\text { LKK, } 30 \text { minutes }\end{array}$ & 7,32 & 5 & $<0,02$ & 5,240 & $\begin{array}{c}< \\
0,0000 \\
3\end{array}$ \\
\hline 3. & $\begin{array}{l}75 \% \text { BAL : } 25 \% \\
\text { LKK, } 60 \text { minutes }\end{array}$ & 7,30 & 6 & $<0,02$ & 6,107 & $\begin{array}{c}< \\
0,0000 \\
3\end{array}$ \\
\hline 4. & $\begin{array}{l}75 \% \text { BAL : } 25 \% \\
\text { LKK, } 90 \text { minutes }\end{array}$ & 7,30 & 5 & $<0,02$ & 4,816 & $\begin{array}{c}< \\
0,0000 \\
3\end{array}$ \\
\hline 5. & $\begin{array}{l}50 \% \text { BAL : } 50 \% \\
\text { LKK, } 30 \text { minutes }\end{array}$ & 7,35 & 6 & $<0,02$ & 5,679 & $\begin{array}{c}< \\
0,0000 \\
3\end{array}$ \\
\hline
\end{tabular}

\begin{tabular}{|c|c|c|c|c|c|c|}
\hline 6. & $\begin{array}{l}50 \% \text { BAL : } 50 \% \\
\text { LKK, } 60 \text { minutes }\end{array}$ & 7,59 & 5 & $<0,02$ & 5,587 & $\begin{array}{c}< \\
0,0000 \\
3\end{array}$ \\
\hline 7. & $\begin{array}{l}50 \% \text { BAL : } 50 \% \\
\text { LKK, } 90 \text { minutes }\end{array}$ & 7,60 & 6 & $<0,02$ & 4,993 & $\begin{array}{c}< \\
0,0000 \\
3\end{array}$ \\
\hline 8. & $\begin{array}{l}25 \% \text { BAL : } 75 \% \\
\text { LKK, } 30 \text { minutes }\end{array}$ & 7,37 & 7 & 0,024 & 6,311 & $\begin{array}{c}< \\
0,0000 \\
3\end{array}$ \\
\hline 9. & $\begin{array}{l}25 \% \text { BAL : } 75 \% \\
\text { LKK, } 60 \text { minutes }\end{array}$ & 7,46 & 7 & $<0,02$ & 5,438 & $\begin{array}{c}< \\
0,0000 \\
3\end{array}$ \\
\hline 10. & $\begin{array}{l}25 \% \text { BAL : } 75 \% \\
\text { LKK, } 90 \text { minutes }\end{array}$ & 7,37 & 6 & $<0,02$ & 3,797 & $\begin{array}{c}< \\
0,0000 \\
3\end{array}$ \\
\hline 11. & $\begin{array}{l}75 \% \text { BAK : } 25 \% \\
\text { LKK, } 30 \text { minutes }\end{array}$ & 7,16 & 6 & $<0,02$ & 3,694 & $\begin{array}{c}< \\
0,0000 \\
3\end{array}$ \\
\hline 12. & $\begin{array}{l}75 \% \text { BAK : } 25 \% \\
\text { LKK, } 60 \text { minutes }\end{array}$ & 7,44 & 7 & 0,081 & 6,908 & $\begin{array}{c}< \\
0,0000 \\
3\end{array}$ \\
\hline 13. & $\begin{array}{l}75 \% \text { BAK : } 25 \% \\
\text { LKK, } 90 \text { minutes }\end{array}$ & 7,54 & 5 & 0,021 & 6,011 & $\begin{array}{c}< \\
0,0000 \\
3\end{array}$ \\
\hline
\end{tabular}

Based on the result of laboratory analysis, the changing value of each parameter of the treatment can be illustrated in the Fig. 1.

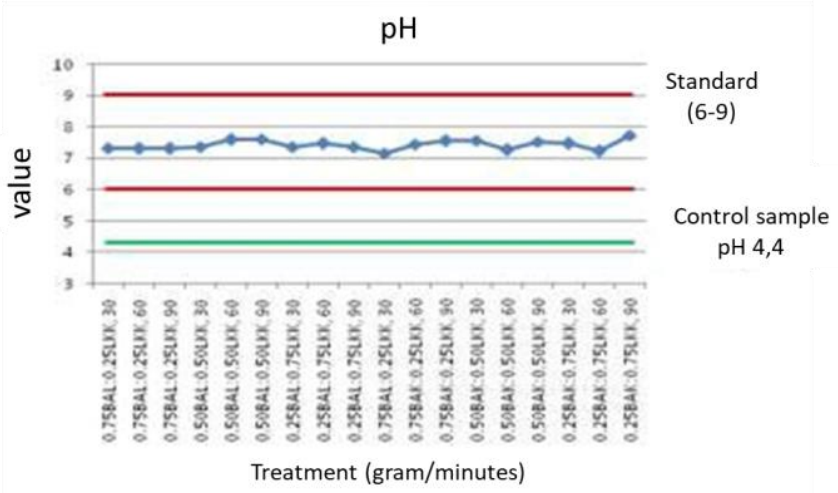

Figure 1. Changing value of $\mathrm{pH}$ before and after treatment. 


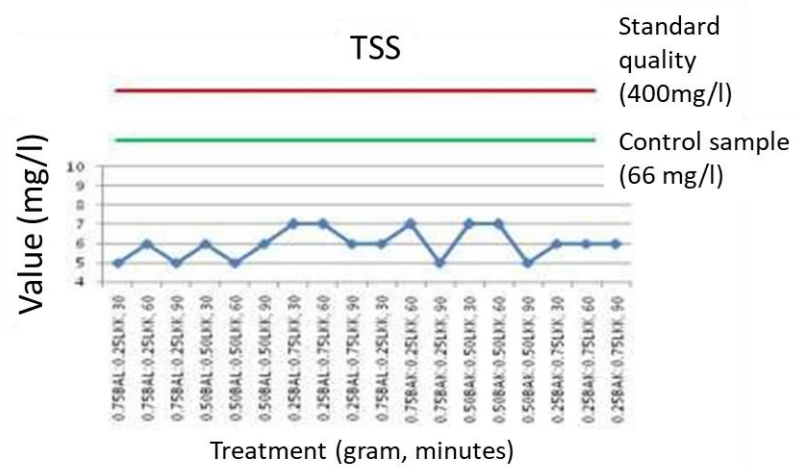

Figure 2. Changing value of TSS before and after treatment

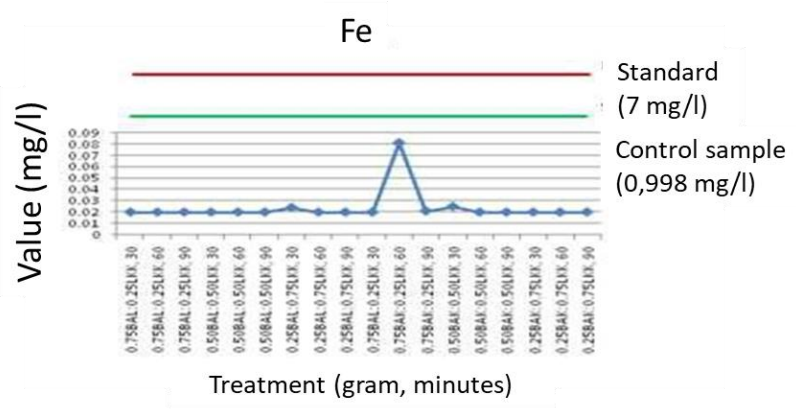

Figure 3. Changing value of Fe before and after treatment

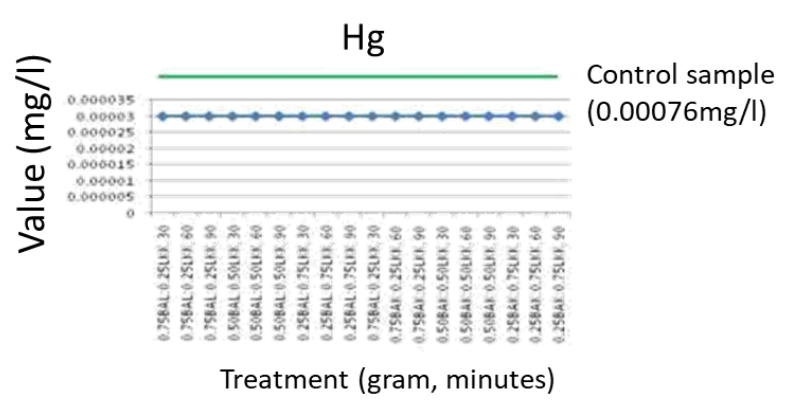

Figure 4. Changing value of Mn before and after treatment

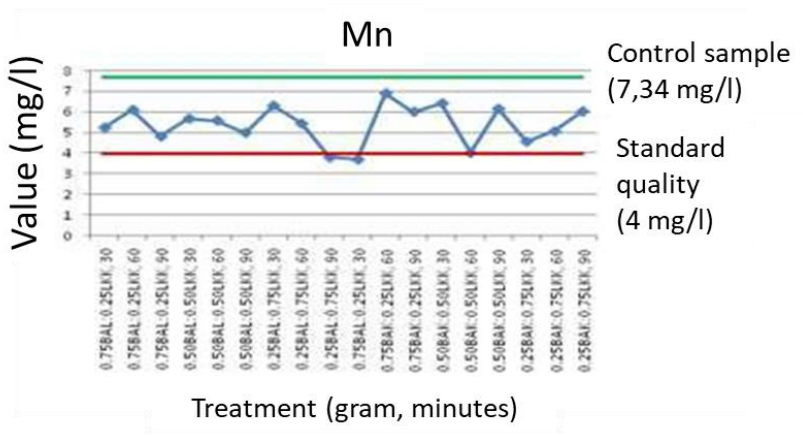

Figure 5. Changing value of $\mathrm{Hg}$ before and after treatment
Based on the research without repeated measure design, it was found out that the treatment working out in reducing all wastewater parameters of coal mining activities in PT. XYZ which meet the environmental quality standard using bentonite adsorbents compiled with limestone of clamshells is the one treated at variant of 0,75 grams of activated bentonite and 0,25 grams of limestone of clamshells stirred for 30 minutes in $250 \mathrm{ml}$ sample of wastewater of coal mining. The reaction which worked at adding bentonite and limestone of clamshells was coagulated adsorption. Bentonite functions as adsorbents during adsorption process, while limestone of clamshells functions in coagulation process.

Adding the limestone into wastewater of coal mining can help increasing $\mathrm{pH}$ to be neutral, in which the main chain reaction in the coagulation process is optimum aluminate compound at neutral $\mathrm{pH}$ [4]. Besides, the content of suspended particles is the main requirement to proceed coagulation [5]. Bentonite added into the wastewater of coal mining has particles of dust and mud. It is these particles that become particles in the wastewater of coal mining processed. [6-9]

Adsorption process works when the wastewater of coal mining is contacted with bentonite. Adsorption is different from absorption. In absorption process the substance absorbed dissolves the absorbent, while in adsorption process the substance adheres to the surface of adsorbent only. The wastewater of coal mining is the solvent containing dissolved substances as heavy metals. If the solvent containing dissolved substances contacts with adsorbents, the dissolved mass transfer from the solvents to the surface of adsorbents. Thus, the concentrate of the dissolved substance in the liquid will decrease.

The main content of bentonite is montmorillonite. The pores on montmorillonite make its surface larger. Hence, its specific surface is open at dispersion in the water as its high capacity to float makes montmorillonite ia able to accept metallic ions [10]. The atom structure of montmorillonite contains with octahedral layer of alumina clamped by silica tetrahedron. At the layer of tetrahedron, there occurs isomorphic substitution between $\mathrm{Si} 4+$ and $\mathrm{Al} 3+$, while at the part of tetrahedron, $\mathrm{Al}$ can be substituted by $\mathrm{Fe}$ or $\mathrm{Mg}$. Isomorphic substitution at the part of tetrahedron and its layer as well cause montmorillonite to have relatively negative contents and then stabilized by cations residing at the 
interlayer part [11].

The exchanging cations on the surface of montmorillonite are mostly $\mathrm{Na}+$ and $\mathrm{Ca} 2+$. These exchangeable cations enable bentonite to separate heavy metal ions from the water through ionic exchanging mechanism. This reaction has stoichiometric quality. Bentonite has property of being pastic and high colloidal and enlarging lattice ability. The occurance of its adsorbent property is caused by its bentonite lattice which is substituted by unbalanced contents. This unbalance condition is caused by the difference between ionic substitution and its valence at tetrahedron, octahedron, or both. So to say, it proves that the compiled bentonite and limestone of clamshells are able to reduce the wastewater parameter of coal mining.

\subsection{Adsorption Efficiency}

To determine the adsorption efficiency value of $\mathrm{pH}, \mathrm{TSS}, \mathrm{Fe}, \mathrm{Mn}$ and $\mathrm{Hg}$ by bentonite adsorbent compiled with limestone of clamshells, the formula is as follows:

$$
E=\frac{c_{o}-c_{e}}{c_{o}} \times 100 \%
$$

Description:

$\mathrm{E}=$ Adsorption Efficiency $(\%)$

$\mathrm{C} 0=$ Value of $\mathrm{pH}, \mathrm{TSS}, \mathrm{Fe}, \mathrm{Mn}$, and $\mathrm{Hg}$ before treatment $(\mathrm{mg} / \mathrm{l})$

$\mathrm{Ce}=$ Value of $\mathrm{pH}$, TSS, Fe, Mn, and $\mathrm{Hg}$ after treatment $(\mathrm{mg} / \mathrm{l})$

This calculation result on the sample of wastewater of coal mining of PT. XYZ can be seen in Table 3 as follows:

Table 3. Adsorption Efficiency of $\mathrm{pH}, \mathrm{TSS}, \mathrm{Fe}, \mathrm{Mn}$ and $\mathrm{Hg}$.

\begin{tabular}{|c|c|c|c|c|c|c|}
\hline \multirow{2}{*}{ No. } & \multirow{2}{*}{ Description } & \multicolumn{5}{|c|}{ Parameter } \\
\hline & & pH & TSS & $\mathbf{F e}$ & Mn & $\mathrm{Hg}$ \\
\hline \multirow{2}{*}{1.} & $75 \%$ BAL : $25 \%$ & \multirow{2}{*}{$66,36 \%$} & 92,42 & 97,99 & 28,61 & 96,05 \\
\hline & LKK, 30 minutes & & $\%$ & $\%$ & $\%$ & $\%$ \\
\hline \multirow{2}{*}{2.} & $75 \%$ BAL : $25 \%$ & \multirow{2}{*}{$65,91 \%$} & 90,91 & 97,99 & \multirow{2}{*}{$16,8 \%$} & 96,05 \\
\hline & LKK, 60 minutes & & $\%$ & $\%$ & & $\%$ \\
\hline \multirow{2}{*}{3.} & $75 \%$ BAL : $25 \%$ & \multirow{2}{*}{$65,91 \%$} & 92,42 & 97,99 & 34,39 & 96,05 \\
\hline & LKK, 90 minutes & & $\%$ & $\%$ & $\%$ & $\%$ \\
\hline \multirow{2}{*}{4.} & $50 \%$ BAL : $50 \%$ & \multirow{2}{*}{$67,04 \%$} & 90,91 & 97,99 & 22,63 & 96,05 \\
\hline & LKK, 30 minutes & & $\%$ & $\%$ & $\%$ & $\%$ \\
\hline \multirow{2}{*}{5.} & $50 \%$ BAL : $50 \%$ & \multirow{2}{*}{$72,5 \%$} & 92,42 & 97,99 & 23,88 & 96,05 \\
\hline & LKK, 60 minutes & & $\%$ & $\%$ & $\%$ & $\%$ \\
\hline
\end{tabular}

\begin{tabular}{|c|c|c|c|c|c|c|}
\hline 6. & $\begin{array}{l}\text { 50\% BAL : } 50 \% \\
\text { LKK, } 90 \text { minutes }\end{array}$ & $72,73 \%$ & $\begin{array}{c}90,91 \\
\%\end{array}$ & $\begin{array}{c}97,99 \\
\%\end{array}$ & $\begin{array}{c}31,97 \\
\%\end{array}$ & $\begin{array}{c}96,05 \\
\%\end{array}$ \\
\hline 7. & $25 \%$ BAL : $75 \%$ & $67,5 \%$ & $\begin{array}{c}89,39 \\
\%\end{array}$ & $\begin{array}{c}97,59 \\
\%\end{array}$ & $\begin{array}{c}14,02 \\
\%\end{array}$ & $\begin{array}{c}96,05 \\
\%\end{array}$ \\
\hline 8. & $\begin{array}{l}25 \% \text { BAL : } 75 \% \\
\text { LKK, } 60 \text { minutes }\end{array}$ & $69,54 \%$ & $\begin{array}{c}89,39 \\
\%\end{array}$ & $\begin{array}{c}97,99 \\
\%\end{array}$ & $\begin{array}{c}25,91 \\
\%\end{array}$ & $\begin{array}{c}96,05 \\
\%\end{array}$ \\
\hline 9. & $\begin{array}{l}25 \% \text { BAL : } 75 \% \\
\text { LKK, } 90 \text { minutes }\end{array}$ & $67,5 \%$ & $\begin{array}{c}90,91 \\
\%\end{array}$ & $\begin{array}{c}97,99 \\
\%\end{array}$ & $\begin{array}{c}48,27 \\
\%\end{array}$ & $\begin{array}{c}96,05 \\
\%\end{array}$ \\
\hline 10. & $\begin{array}{l}75 \% \text { BAK : } 25 \% \\
\text { LKK, } 30 \text { minutes }\end{array}$ & $62,73 \%$ & $\begin{array}{c}90,91 \\
\%\end{array}$ & $\begin{array}{c}97,99 \\
\%\end{array}$ & $\begin{array}{c}49,67 \\
\%\end{array}$ & $\begin{array}{c}96,05 \\
\%\end{array}$ \\
\hline 11. & $\begin{array}{l}75 \% \text { BAK : } 25 \% \\
\text { LKK, } 60 \text { minutes }\end{array}$ & $69,09 \%$ & $\begin{array}{c}89,39 \\
\%\end{array}$ & $\begin{array}{c}91,88 \\
\%\end{array}$ & $5,88 \%$ & $\begin{array}{c}96,05 \\
\%\end{array}$ \\
\hline 12. & $\begin{array}{l}75 \% \text { BAK : } 25 \% \\
\text { LKK, } 90 \text { minutes }\end{array}$ & $71,36 \%$ & $\begin{array}{c}92,42 \\
\%\end{array}$ & $\begin{array}{c}97,89 \\
\%\end{array}$ & $\begin{array}{c}18,11 \\
\%\end{array}$ & $\begin{array}{c}96,05 \\
\%\end{array}$ \\
\hline 13. & $\begin{array}{l}50 \% \text { BAK : } 50 \% \\
\text { LKK, } 30 \text { minutes }\end{array}$ & $71,82 \%$ & $\begin{array}{c}89,39 \\
\%\end{array}$ & $\begin{array}{c}97,49 \\
\%\end{array}$ & $\begin{array}{c}12,52 \\
\%\end{array}$ & $\begin{array}{c}96,05 \\
\%\end{array}$ \\
\hline 14. & $\begin{array}{l}50 \% \text { BAK : } 50 \% \\
\text { LKK, } 60 \text { minutes }\end{array}$ & $65 \%$ & $\begin{array}{c}89,39 \\
\%\end{array}$ & $\begin{array}{c}97,99 \\
\%\end{array}$ & $\begin{array}{c}45,26 \\
\%\end{array}$ & $\begin{array}{c}96,05 \\
\%\end{array}$ \\
\hline 15. & $\begin{array}{l}50 \% \text { BAK : } 50 \% \\
\text { LKK, } 90 \text { minutes }\end{array}$ & $70,91 \%$ & $\begin{array}{c}92,42 \\
\%\end{array}$ & $\begin{array}{c}97,99 \\
\% \\
\end{array}$ & $\begin{array}{c}16,13 \\
\% \\
\end{array}$ & $\begin{array}{c}96,05 \\
\% \\
\end{array}$ \\
\hline 16. & $\begin{array}{l}25 \% \text { BAK : } 75 \% \\
\text { LKK, } 30 \text { minutes }\end{array}$ & $69,54 \%$ & $\begin{array}{c}90,91 \\
\%\end{array}$ & $\begin{array}{c}97,99 \\
\%\end{array}$ & $\begin{array}{c}37,83 \\
\%\end{array}$ & $\begin{array}{c}96,05 \\
\%\end{array}$ \\
\hline 17. & $\begin{array}{l}25 \% \text { BAK : } 75 \% \\
\text { LKK, } 60 \text { minutes }\end{array}$ & $64,09 \%$ & $\begin{array}{c}90,91 \\
\%\end{array}$ & $\begin{array}{c}97,99 \\
\%\end{array}$ & $\begin{array}{c}30,95 \\
\%\end{array}$ & $\begin{array}{c}96,05 \\
\%\end{array}$ \\
\hline 8. & $\begin{array}{l}25 \% \text { BAK : } 75 \% \\
\text { LKK, } 90 \text { minutes }\end{array}$ & $75,68 \%$ & $\begin{array}{c}90,91 \\
\%\end{array}$ & $\begin{array}{c}97,99 \\
\%\end{array}$ & $\begin{array}{c}17,87 \\
\%\end{array}$ & $\begin{array}{c}96,05 \\
\%\end{array}$ \\
\hline
\end{tabular}

\subsection{Effect of Mass and Contacting Time}

The bentonite and limestone of clamshells utilized as adsorbent in this research were set in a various amount and contacting time. The variants of adsorbent mass are meant to find out the effect of adding bentonite weight and limestone of clamshells on the force of adsorption and to determine the weight of bentonite and limestone of clamshells needed to achieve balance condition.

The adsorption process was conducted by stirring method using shaker with the speed of $200 \mathrm{rpm}$. This shaker tool works so as the adsorption process keeps going on at constant temperature and speed. Contacting time is one important factor in the adsorption process since it is needed to balance between the dissolved substance adsorbed and the existing solvents.

The data analysis of each parameter of wastewater after being treated with various bentonite masses, limestone of clamshells and contacting time can be seen in the following Fig. 6 to Fig. 10. 




Figure 6. Effect of Mass \& Contact Time on Increasing pH

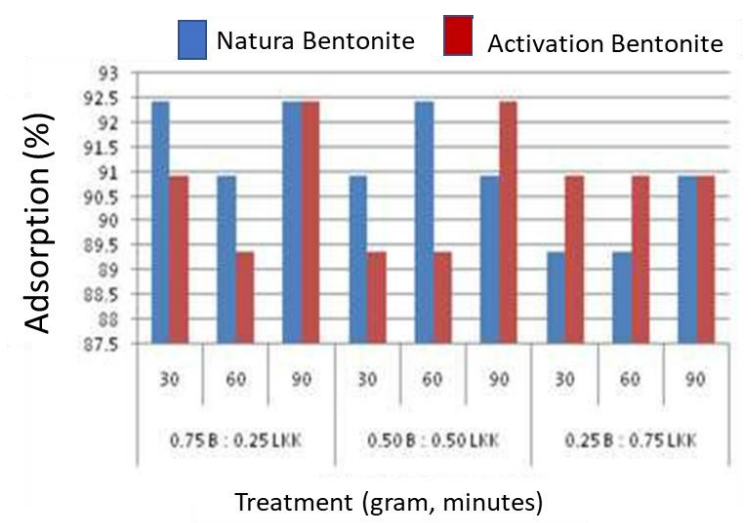

Figure 7. Effect of Mass \& Contact Time on Adsorption of TSS Effect of Mass and Contacting Time on Adsorption of Fe



Figure 8. Effect of Mass \& Contact Time on Fe Adsorption



Figure 9. Effect of Mass \& Contact Time on Mn Adsorption

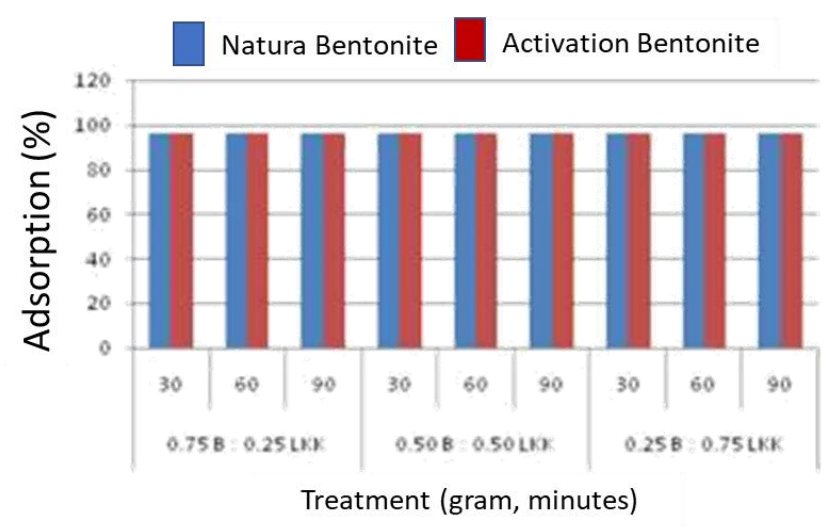

Figure 10. Effects of Mass \& Contact Time on Hg Adsorption

From the above graphics, it can be seen that adsorption occurs at all surfaces, but its amount is determined by the width of adsorbent surface which directly contacts with adsorbent. The amount of adsorbent equals to the width of its specific surface. The wider the surface, the more adsorption will be [12]. At natural adsorbent and activated bentonite with the mass of 0,75 gram, it has pores and widest surface to compare with the mass of 0,50 gram and 0,25 gram, thus its adsorption force on TSS and heavy metals become higher. This indicates that the amount of adsorbent mass plays significant role in the adsorption force. The amount of bentonite used in adsorption also affects the amount of TSS and heavy metals which are adsorbed. The weight of adsorbent which is adsorbed gets higher as the amount of bentonite weight used.

What makes the adsorption force increases on TSS and heavy metals is because of ionic exchanging reaction. Here, an amount of ionic mass on TSS and heavy metals transfer to the surface of 
bentonite. This exchanging reaction is a uniquely chemical adsorption. Ionic transfer is likely to happen if some ions at the adsorbents of TSS and heavy metals change the position of existing positive ions in bentonite adsorbent, thus causing the positive ions transfer into the liquid. This may be caused by Coulomb force between negative ions in the adsorbent and positive ions at TSS and heavy metals as adsorbent.

Referring to the result of analysis, the natural bentonite of 0,75 gram is the optimal mass in adsorbing TSS, Fe, Mn, and [7]-[8] $\mathrm{Hg}$ in wastewater of coal mining of PT. XYZ, and so is activated bentonite. Yet, at the same amount of mass, activated bentonite has better capacity of adsorption than natural bentonite. It is due to the activated bentonite having more active pores and open for adsorption than does the natural bentonite.

Various adsorptions of TSS and heavy metals is also found out at the difference of contacting time. In some samples, there were increasing adsorption of TSS and heavy metals as does the contacting time. In all, at the contacting time of 30 minutes, the amount of TSS and heavy metals adsorbed was quite a little as the interacting time between ions at TSS and the adsorbents at heavy metals during active sites was relatively in a short time. But at the contacting time of 60 minutes, the amount of TSS and heavy metals adsorbed was decreasing. It was found out that the condition of ions at TSS and heavy metals were not entering into the pores of bentonite as they could not enter in time. Therefore, the possibility of that condition is that the ions at TSS and heavy metals which were already reacted in chains with active sites at existing bentonite were unattached from the pores of bentonite during adsorption process as the chain between ions at TSS and ions at heavy metals with active site at bentonite is the chain reaction of Van der Waals [13].

The decreasing capacity of adsorption is also caused by the use of shaker tool with high speed. It can remove the attached adsorbates at the surface of adsorbent. The speed of more than $90 \mathrm{rpm}$ will make the chains between adsorbents and adsorbates particles to remove. In addition, overspeed stirring will make adsorbents unable to make strong chains with the particles of heavy metals. While the contacting time at 90 minutes, the amount of ions and the adsorbed heavy metals are the most to compare with other contacting time. The adsorption efficiency shows that the balanced adsorption of TSS and heavy metals using natural and activated bentonite were achieved at the contacting time of 90 minutes as, in general, ions adsorption at TSS and heavy metals occurs slower before contacting time of 90 minutes.

Clamshells also contribute to the reducing parameter of TSS and heavy metals. It is due to the calcium carbonate $(\mathrm{CaCO} 3)$ they contain higher than limestone, egg shells, and ceramics so as they are used as media to separate between water and metallic ions.

\subsection{Environmental Impacts of Wastewater of Coal Mining}

The coal mining activities that produce wastewater certainly impact on the surrounding environment of the mining sites. Three components of environment are potential to cause primary impact which in turn causes other environmental impacts.

The impacts resulted from wastewater of coal mining activities are indirectly felt by people around the sites as the impacts accumulate in years to come. By doing well-managed wastewater of coal mining activities, as in utilization of bentonite adsorbents and limestone of clamshells, it is expected that the impacts caused by wastewater of coal mining activities be minimalized by decreasing the contents of pollutants in the wastewater to achieve the standard quality of environment in compliance with the testing conducted in the laboratory producing adsorption efficiency of $\mathrm{pH}$ for $68,62 \%$, TSS for $90,91 \%$, Fe for $97,60 \%$, Mn for $26,71 \%$, and $\mathrm{Hg}$ for $96,05 \%$, so as to achieve environmentally-friendly coal mining activities.

\section{Conclusion}

The properties of wastewater of coal mining of PT. XYZ in compliance with the standard quality of environment of Ministry Regulation LH No. 113 year 2003 are pH 4,40, TSS 66 mg/l, Fe 0,998 mg/l, Mn 7,340 mg/l, and Hg 0,00076 mg/l. The compiled bentonite and limestone of clamshells are able to reduce the wastewater parameter of coal mining. The adsorption efficiency at compiled bentonite and limestone in reducing the wastewater parameter of coal mining has approximate values: $\mathrm{pH} 68,62 \%$, TSS 90,91\%, Fe 97,60\%, Mn 26,71\%, and $\mathrm{Hg}$ $96,05 \%$. The mass and contacting time at compiled bentonite and limestone effect on reducing the wastewater parameter of coal mining. 


\section{References}

[1] Pusat Litbang Tekmira, "Statistik Batubara Indonesia." Pusat Litbang Tenologi Mineral dan Batubara, pp. 1-13, 2006.

[2] M. Naswir, S. Arita, P. Jumaida, D. M. Lince, and Tasmin. 2018. The development of nanotechnology bentonite as adsorbent of metal Cadmium (Cd). International Conference on Science and Technology 2018. Vol. 1116, no. 042026, pp. 1-9.

[3] M. Naswir and I. Lestari. 2014. Characterization Active Carbon and Clum Shell In Reducing pH, Color, COD, Fe and Organic Matter on Peat Water. International Journal of Innovative Research in Advanced Engineering (IJIRAE), vol. 1, no. 11, pp. 137-146.

[4] T. A. Hassan, V. K. Rangari, R. K. Rana, and S. Jeelani. 2013. Ultrasonics Sonochemical effect on size reduction of $\mathrm{CaCO} 3$ nanoparticles derived from waste eggshells. Ultrasonics - Sonochemistry, vol. 20, no. 5, pp. 1308-1315.

[5] T. Fazal, A. Mushtaq, F. Rehman, A. Ullah, and N. Rashid. 2017. Bioremediation of textile wastewater and successive biodiesel production using microalgae. Renewable and Sustainable Energy Reviews, no. February, pp. 1-20.

[6] D. Natalia et al. 2019. Bentonite utilization to removal nitrogen from palm oil mill. International Journal of Chemical Science, vol. 3, no. 4, pp. 89-92.

[7] M. Naswir, S. Arita, W. Hartati, L. Septiarini, and Y. G. Wibowo. 2019. Activated Bentonite: Low Cost Adsorbent to Reduce Phosphor in Waste Palm Oil. International Journal of Chemistry, vol. 11, no. 2, pp. 67-76.
[8]. M. Naswir, S. Arita, Marsi, and Salni. 2015. Optimization of Peat Water Treatment Be Clean Water in the Lowlands Technology with Local Raw Material Formulation. Asian Journal of Chemistry. ISSN 0970-7077, vol .27 no.11 pp 3951-3956.

[9]. M. Naswir, S. Arita, W. Hartati, L. Septiarini, and Y. G. Wibowo. 2019. Utilization of activated bentonite to reduce nitrogen on palm oil mill," International Journal of Chemical Science, vol. 3, no. 4, pp. 8992.

[10] J. Ma, J. Zou, L. Li, C. Yao, T. Zhang, and D. Li. 2013. Applied Catalysis B : Environmental Synthesis and characterization of $\mathrm{Ag} 3 \mathrm{PO} 4$ immobilized in bentonite for the sunlight-driven degradation of Orange II. Applied Catalysis B, Environmental, vol. 134-135, pp. 1-6.

[11] H. Lyu, Q. Zhang, and B. Shen. 2020. Chemosphere Application of biochar and its composites in catalysis. Chemosphere, vol. 240, p. 124842.

[12] Y. G. Wibowo, B. S. Ramadan, and M. Andriansyah. 2019. Simple Technology to Convert Coconut Shell Waste into Biochar: A Green Leap Towards Achieving Environmental Sustainability," Jurnal Presipitasi. Media Komunikasi dan Pengembangan Teknik Lingkungan, vol. 16, no. 2, pp. 15-21.

[13] T. N. de Matos, J. J. L. Léon, I. L. S. Almeida, S. M. L. O. Marcionilio, H. C. Rezende, and C. S. T. Araújo. 2017. Elucidation of mechanism involved in adsorption of $\mathrm{Pb}$ (II) onto lobeira fruit ( Solanum lycocarpum ) using Langmuir, Freundlich and Temkin isotherms. Microchemical Journal, vol. 137, no. ii, pp. 348-354. 